\title{
VALIDATION OF ANALYTICAL METHOD FOR DETERMINATION OF FUROSEMIDE IN EXTEMPORANEOUS SYRUP
}

Introduction. Extreme syrups can be manufactured using substances or ready medicinal drugs as the active pharmaceutical ingredient. There is a necessity in the development and validation of analytical methods that can be used for quality control of pharmaceutical manufacturing of syrups containing furosemide.

The aim of the study - to develop and validate assay method for furosemide in extemporaneous syrups prepared from both pure substance and finished products.

Research Methods. For proposed UV spectrophotometric assay method the conditions of analysis, sample preparation and validation characteristics were defined. Suspensions of substance and crushed commercial tablets were dissolved in $0.1 \mathrm{M}$ sodium hydroxide solution and evaluated spectrophotometrically in ultraviolet region of light at a wavelength $271 \mathrm{~nm}$ using method of specific absorbance.

Results and Discussion. Samples comply with the Beer-Lambert Bouguer law within the concentration range of $8 \times 10^{-3}-1.2 \times 10^{-2} \mathrm{mg} / \mathrm{ml}$ with correlation coefficients $\geq 0.9981$. The uncertainty of the methods was well within the critical value of the error $\left(0.72 \% \leq \max \Delta_{A S}\right)$ for both samples of syrup containing pure substance and commercial tablets. Recovery studies for furosemide in syrup samples of substance and crushed commercial tablets yielded $99.92 \pm 0.54 \%$ and $99.14 \pm 0.16 \%$ respectively. Assay limit of $\pm 10 \%$ by the validation parameters: specificity, linearity, precision, accuracy within the range of 80-120\% of the nominal contents was met by all compounded preparations.

Conclusions. The results of validation proved that this method can be reproduced correctly and is suitable for use in pharmaceutical analysis. Adoption of this method is planned in evaluating uniformity of content and, in combination of other methods, ascertain chemical stability studying of compounded furosemide syrups.

KEY WORDS: furosemide; extemporaneous preparation; UV spectrophotometry; validation of analytical method.

INTRODUCTION. Stability of extemporaneous preparations has been of interest to compounding pharmacists since the use of finished products (tablets, capsules, injections) as a direct source of active pharmaceutical ingredients. Excipients of these finished products do not only alter the microbial stability of the compounded preparations but may cause non-uniform distribution and also degradation of the active component of interest, leading to actual loss in the claimed quantity of labelled dose. Verified assay method is pertinent to ascertain the uniformity of a compounded formulation [1-7].

The British, European, Indian and Japanese pharmacopoeias recommend titrimetry for pure pharmaceutical substance and the UV-spectrophotometric assay methods for tablet and injection dosage forms. Taking into consideration that compounded syrups can be prepared using pure pharmaceutical substances or manufactured products (such as tablets, capsules etc) as active (c) D. Alfred-Ugbenbo, O. A. Zdoryk, V. A. Georgiyants, 2017. pharmaceutical ingredient [8-11], there is need to validate potential analytical methods that could be used for compounded syrups.

The purpose of our work is to validate an ultraviolet spectroscopic method for determining furosemide in such extemporaneous syrups.

RESEARCH METHODS. For our research we took two syrups, their composition is given below: Composition Syrup 1 Composition Syrup 2

Furosemide $0.5 \mathrm{~g} \quad$ Furosemide ex tab $0.5 \mathrm{~g}$ Syrup USP $100 \mathrm{ml} \quad$ Syrup USP $100 \mathrm{ml}$

Furosemide substance from Ipca Laboratories Ltd. India (certificate of analysis batch 5074HRII), furosemide tablets $40 \mathrm{mg}$ (Arterium batch 118840, Ukraine), furosemide tablets $40 \mathrm{mg}$ (Sanofi batch 114402, Ukraine) and Sucrose (pharmaceutical grade). Simple syrup (85 \% w/v) United States Pharmacopoeia (USP) was compounded according to instructions for its preparation $[12,13]$. Class A Volumetric glassware, filter paper (FILTRAK®Acido 
Hydrochlorico Extraca), UV-spectrophotometer (Thermoscientific Evolution 60S) with $10 \mathrm{~mm}$ quartz cells, mortar, pestle, analytical balance (AXIS, Poland ALN220). All reagents and solvents meet and were prepared in accordance with the requirements of The State Pharmacopoeia of Ukraine (SPU) which also agrees with the European Pharmacopoeia [14].

Compounding technology of Syrup: levigate accurately weighed $500 \mathrm{mg}$ of furosemide substance (or equivalent quantity of powdered tablet mass) with a small portion of syrup to form a paste. Add syrup gradually with stirring to form a homogenous mixture. Fill the mixture with the same base up to $100 \mathrm{ml}$ to form a $5 \mathrm{mg} / \mathrm{ml}$ suspension.

Method: Weigh quantity of $5 \mathrm{mg} / \mathrm{ml}$ compounded suspension, equivalent to $50 \mathrm{mg}$ of furosemide, on an analytical balance. Transfer the suspension into a $100 \mathrm{ml}$ volumetric flask, add $10 \mathrm{ml}$ of $0.1 \mathrm{M}$ sodium hydroxide, shake and allow standing for 20 minutes. Dilute with the same solvent to $100 \mathrm{ml}$. Dilute $2 \mathrm{ml}$ of the obtained solution to $100 \mathrm{ml}$ with $0.1 \mathrm{M}$ sodium hydroxide. Measure the absorbance at $271 \mathrm{~nm}$ using $0.1 \mathrm{M}$ sodium hydroxide as the compensation solution.

Calculate the content of $\mathrm{C}_{12} \mathrm{H}_{11} \mathrm{C}_{1} \mathrm{~N}_{2} \mathrm{O}_{5} \mathrm{~S}$ taking 580 as the value of $\mathrm{A}(1 \%, 1 \mathrm{~cm})$ as the maximum at $271 \mathrm{~nm}$ using the formula:

$$
X(\%)=\frac{A_{1}}{A_{\text {nom }}} \times D \times C_{S} \times 100 ; \quad D=\frac{V_{D}}{m_{t}},
$$

where $\mathrm{A}_{1}$ - observed absorbance,

$A_{\text {nom }}\left(A_{\text {nom }}=A \frac{1 \%}{1 \mathrm{~cm}} \times 0.001\right)-$ specific $0.01 \mathrm{~g} / \mathrm{L}$ solution,

D - dilution of analysed sample,

$\mathrm{C}_{\mathrm{s}}$ - final concentration $(\mathrm{mg} / \mathrm{ml})$ of analysed solution,

$m_{t}-$ mass of analyte.

RESULTS AND DISCUSSION. The validation criteria for tolerance content $\pm 10 \%$ were defined according to the requirements of SPU and the work on development and validation of quality assurance methods for compounded preparations [15]: range $80-120 \%$, permitted deviation in content $(B, \%)$ $\pm 10 \%$, critical value of the error $\left(\max \Delta_{\mathrm{As}}, \%\right) 3.2 \%$, maximum systematic error $\left(\delta_{\max }, \%\right) 1.02 \%$, coefficient of determination $\left(R^{2}\right) 0.9924, y$-intercept on the calibration graph $(a, \%) 4.7 \%$, uncertainty of absorbance $\left(\delta_{\text {abs }}, \%\right) 2.43 \%$.

During method development $0.1 \mathrm{M}$ sodium hydroxide was selected as solvent, based on pharmacopoeial recommendations [8-11] on furosemide's solubility.

In the prognosis of the analytical method uncertainty, the maximum permissible errors during operations associated with use of glassware [14] and value of uncertainty in final analytical operation, $\Delta_{\mathrm{FAO}}(0.49)$ [15] were taken into consideration. The uncertainty of the method was found to be $0.72 \%$, which falls within specified limits $\Delta_{\mathrm{As}} \leq \max \Delta_{\mathrm{As}}$.

Specificity: Fig. 1 shows that neither sucrose nor the excipients in tablet significantly interfered with the result from spectrophotometric determination of furosemide.

Also, a correspondence in peaks at wavelength $271 \mathrm{~nm}$ for both substance and tablets is seen, thus, the method is specific for furosemide. The influence of placebo (only syrup) was taken by repeating the procedure in the section method with just the dispersion vehicle. Its influence was calculated with the formula:

$$
\delta_{\text {noise }}=\frac{A_{\text {blank }}}{A_{\text {nom }}} \times 100 \%,
$$

where its absorbance, $A_{\text {blank }}=0.001 ; A_{s t}=0.580$.

Contribution of the placebo to the total absorbance of the analyte is $0.17 \%$. Its influence is within the limits of the criteria $\left(\leq \delta_{\max }=1.7 \%, \leq \delta_{\text {abs }}=2.43\right.$ ).

The maximum uncertainty of absorbance for our preparations was calculated using the formula:

$$
\delta_{\text {abs }}=\sqrt{2} \times \frac{100 \times \Delta A}{A_{\text {nom }}}=\sqrt{2} \times \frac{100 \times 0.01}{0.520}=2.43,
$$
[9].

where $\Delta \mathrm{A}$ - tolerance for absorbance, \pm 0.01

Linearity and range. The absorbance samples was measured at a concentration range of $8 \times 10^{-3}-$ $1.2 \times 10^{-2} \mathrm{mg} / \mathrm{ml}$, corresponding to $80-120 \%$ nominal concentration of furosemide. The values in the linearity graphs were converted to nominal coordinates [15]. The linear graphs below show their corresponding linear dependence. The regression line equations obtained $Y=1.04 \cdot X-3.99$ and $Y=0.96 \cdot X+3.42$ for substance and tablets respectively suspended in syrup (Fig. 2, Table 1), in conformity with Beer-Lambert's law. The coefficients of determination were $\geq 0.9981$ for all samples.

Accuracy of the method (Table 1) was ascertained at 5 levels with 3 repetitions at each level. Quantity equivalent to $80 \%, 90 \%, 100 \%$, $110 \%$ and $120 \%$ was added to samples. The mean percentage recoveries of the substances as against theoretical values ranged between 98.41 to $101.20 \%$ for furosemide substance and 98.20 to $99.68 \%$ for furosemide tablet in syrup. The systematic errors (substance in syrup $-0.08 \%$, tablets in syrup $-0.86 \%$ ) indicate the accuracy of the method.

Precision: The absorbance of $10 \mu \mathrm{g} / \mathrm{ml}$ solutions from commercial tablets in syrup for two brands were observed at different times of the day (intraday) and on different days (interday) by different analysts (Table 2). The cumulative relative standard deviation (RSD, \%), which is a measure of precision, was 0.73 . The method was found to be precise. 


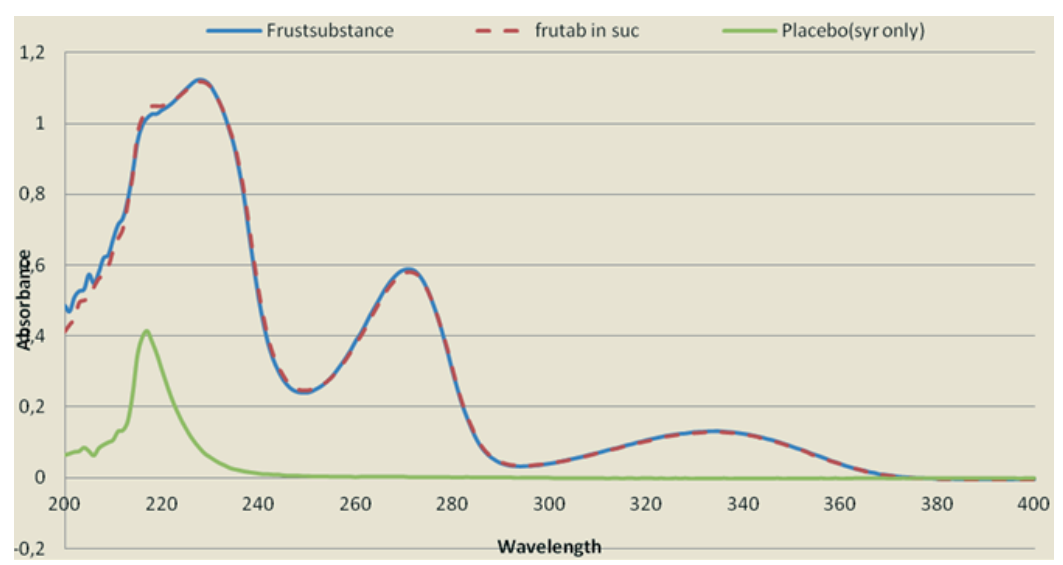

Fig. 1. UV Spectrum for furosemide substance, tablets and placebo (sucrose).

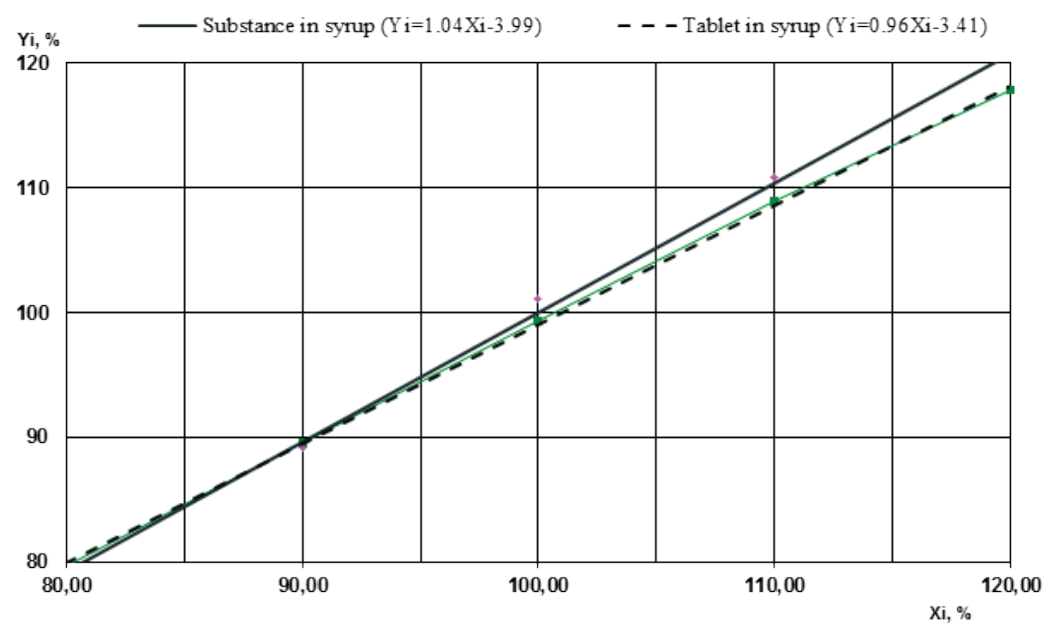

Fig. 2. Linearity curve for furosemide in syrup samples in normalized coordinates.

Table 1 - Validation characteristics of the method for quantitative determination of furosemide in compounded preparations

\begin{tabular}{|c|c|c|}
\hline Validation parameters & Substance in syrup & Tablets in syrup \\
\hline \multicolumn{3}{|c|}{ Accuracy and precision } \\
\hline $\mathrm{Z}, \%$ & 99.92 & 99.14 \\
\hline $\mathrm{S}, \%$ & 0.99 & 0.54 \\
\hline$\Delta_{7}, \%$ & 1.74 & 0.95 \\
\hline$\delta, \%$ & 0.08 & 0.86 \\
\hline \multicolumn{3}{|c|}{ Linearity } \\
\hline $\mathrm{b}$ & 1.04 & 0.96 \\
\hline $\mathrm{S}_{\mathrm{h}}$ & 0.0134 & 0.0055 \\
\hline$a$ & -3.99 & 3.42 \\
\hline $\mathrm{S}$ & 1.3501 & 0.5546 \\
\hline $\mathrm{S}_{0}^{\mathrm{a}}$ & 0.73 & 0.30 \\
\hline$r$ & 0.9989 & 0.9998 \\
\hline
\end{tabular}

Robustness. Deliberate variations in wavelength and extraction time were made to show the reliability of the method. Syrups containing $50 \mathrm{mg}$ of furosemide was shaken with $10 \mathrm{ml} 0.1 \mathrm{M}$ sodium hydroxide and were allowed to stand for 20,40 and 60 minutes before further sample preparation procedures. The method was found to be robust (Table 3).

Stability of analytical solutions of observed and found to be stable for 1 hour (Table 4). Time zero minute is counted from the moment the final dilution is made. There was no significant change in $\mathrm{pH}$ or absorbance.

Metrological characteristics of the method do not exceed the critical value of the error (3.2\%) and are characterized by qualitative analytical indicators. This method can be correctly reproduced in the laboratory.

CONCLUSIONS. A non-derivative UV-spectrophotometric method has been developed and validated for content determination of furosemide 
Table 2 - Repeatability and reproducibility of the method

\begin{tabular}{|c|c|c|}
\hline \multirow{2}{*}{ No. of a sample } & \multicolumn{2}{|c|}{ Zi, \% } \\
\hline & Arterium batch 118840 & Sanofi batch 114402 \\
\hline 1 & 100.00 & 100.34 \\
\hline 2 & 100.12 & 100.34 \\
\hline 3 & 99.83 & 100.05 \\
\hline 4 & 99.83 & 100.52 \\
\hline 5 & 100.17 & 100.17 \\
\hline 6 & 100.00 & 100.12 \\
\hline 7 & 100.00 & 100.17 \\
\hline 8 & 99.81 & 99.84 \\
\hline 9 & 99.74 & 100.17 \\
\hline 10 & 99.77 & 99.83 \\
\hline 11 & 99.65 & 99.98 \\
\hline 12 & 99.65 & 99.98 \\
\hline 13 & 99.67 & 99.46 \\
\hline 14 & 99.62 & 100.00 \\
\hline 15 & 99.82 & 99.83 \\
\hline Mean $(Z, \%)$ & 99.84 & 100.05 \\
\hline$Z_{\text {intra }}, \%$ & \multicolumn{2}{|c|}{99.95} \\
\hline $\mathrm{S}_{\mathrm{z}}, \%$ & 0.17 & 0.26 \\
\hline $\mathrm{SD}_{\mathrm{z}}, \%$ & \multicolumn{2}{|c|}{0.43} \\
\hline$\Delta_{\text {intra }}, \%$ & \multicolumn{2}{|c|}{0.73} \\
\hline
\end{tabular}
(95\%).

Note. $Z_{\text {intra }}$ - cumulative mean, $S_{z}-$ standard deviation, $\mathrm{SD}_{\mathrm{z}}-$ relative standard deviation, $\Delta_{\text {intra }}-$ relative confidence interval

Table 3 - Study of robustness for the method

\begin{tabular}{|l|c|c|c|}
\hline \multirow{2}{*}{\multicolumn{1}{|c|}{ Parameter }} & \multicolumn{3}{|c|}{ Absorbance } \\
\cline { 2 - 4 } & Minimum & Optimum & Maximum \\
\hline Variation in wavelength & $270 \mathrm{~nm}$ & $271 \mathrm{~nm}$ & $272 \mathrm{~nm}$ \\
\cline { 2 - 4 } & 0.579 & 0.580 & 0.577 \\
\hline Variation in extraction time (20 min) & 0.579 & 0.580 & 0.580 \\
\hline
\end{tabular}

Table 4 - Absorbance stability of analytical solutions

\begin{tabular}{|c|c|c|c|c|c|c|c|c|c|}
\hline \multirow{2}{*}{ Brand } & \multicolumn{5}{|c|}{ Period of study, min } & \multirow{2}{*}{ mean } & \multirow{2}{*}{ RSDt, \% } & \multirow{2}{*}{$\Delta \mathrm{t}, \%$} & \multirow{2}{*}{$\max \delta, \%$} \\
\hline & 0 & 15 & 30 & 45 & 60 & & & & \\
\hline \multirow{4}{*}{$\begin{array}{l}\text { Arterium batch } \\
118840\end{array}$} & 0.580 & 0,579 & 0.580 & 0.580 & 0.579 & \multirow[t]{4}{*}{0.5796} & \multirow[t]{4}{*}{0.15} & \multirow[t]{4}{*}{0.32} & \multirow[t]{4}{*}{1.02} \\
\hline & 0.581 & 0.581 & 0.579 & 0.579 & 0.579 & & & & \\
\hline & 0.581 & 0.580 & 0.580 & 0.579 & 0.577 & & & & \\
\hline & 0.5807 & 0.5800 & 0.5797 & 0.5793 & 0.5783 & & & & \\
\hline \multirow{2}{*}{ Brand } & & Perio & of study & $t, \min$ & & \multirow{2}{*}{ mean } & \multirow{2}{*}{ RSDt, \% } & \multirow{2}{*}{$\Delta \mathrm{t}, \%$} & \multirow{2}{*}{$\max \delta, \%$} \\
\hline & 0 & 15 & 30 & 45 & 60 & & & & \\
\hline \multirow{4}{*}{$\begin{array}{l}\text { Sanofi batch } \\
114402\end{array}$} & 0.582 & 0.580 & 0.581 & 0.579 & 0.580 & \multirow[t]{4}{*}{0.5807} & \multirow[t]{4}{*}{0.13} & \multirow[t]{4}{*}{0.27} & \multirow[t]{4}{*}{1.02} \\
\hline & 0.582 & 0.581 & 0.581 & 0.581 & 0.580 & & & & \\
\hline & 0.581 & 0.581 & 0.581 & 0.581 & 0.579 & & & & \\
\hline & 0.5187 & 0.5807 & 0.5810 & 0.5803 & 0.5797 & & & & \\
\hline
\end{tabular}

Note. $\Delta \mathrm{t}, \%$ - confidence interval over the time period, max $\delta$ - maximum error.

in compounded syrups. The assay method meets acceptance criteria for the assay limits by the validation parameters: specificity, linearity, precision, accuracy within the range of $80-120 \%$ of the nominal content. Based on the results of validation studies, it has been substantiated and verified experimentally that this method can give reliable results, reproducible and be suitable for quality control of furosemide. Adoption of this method is planned in evaluating uniformity of content and, in combination with other methods, to ascertain chemical stability study of compounded furosemide syrups. 


\section{LIST OF LITERATURE}

1. Compounding in Nigeria / D. Alfred-Ugbenbo, O. A. Zdoryk, V. A. Georgiyants [et al.] // Int. J. Pharm. Compd. - 2016. - 20, №. 3. - P. 89-192

2. Валиев А. Х. Изучение химической стабильности глазных капель цесразолина натрия аптечного приготовления / А. Х. Валиев, А. А. Здорик, В. А. Георгиянц // Химико-срармац. журн. - 2014. - 48, № 11. - C. 51-53.

3. AlfredUgbenbo D. S. Prescription analysis for extemporaneous preparations in hospital pharmacies of Southern Nigeria / D. S. AlfredUgbenbo, O. A. Zdoryk, V. A. Georgiyants // Управління, економіка та забезпечення якості в фрармації. - 2016. - № 3. - С. 46-52.

4. Strength and stability testing for compounded preparations / L. V. Allen, G. S. Bassani, E. J. Elder [et al.] // United States Pharmacopoeia 2015. Retrieved from: [April, 2017] http://www.usp.org/sites/default/files/u sp_ $\mathrm{pdf} / \mathrm{EN} /$ healthcareProfessionals/strength-stabilitytesting- compounded-preparations.pdf

5. Loyd V. A. Current \& practical compounding information for the pharmacist / V. A. Loyd // Secundum Artem. - 2012. - 17, № 1. - P. 1-4.

6. Navid F. Stability of sunitinib in oral suspension / F. Navid, R. Christensen, P. Minkin [et al.] // Ann. Pharmacother. - 2008. - № 42. - P. 962-966.

7. Stability of cyclophosphamide in extemporaneous oral suspensions / R. Kennedy, D. Groepper, M. Tagen [et al.] // Ann. Pharmacother. - 2010. - № 44. - P. 295301.

8. Japanese pharmacopoeia. $-16^{\text {th }}$ ed. [Електронный ресурс] Ministry of Health, Labour and Welfare: Tokyo, 2011. - 2220p

9. European pharmacopoeia. $-7^{\text {th }}$ ed. Council of Europe: Strasbourg, 2011. - 3299p.

10. British pharmacopoeia 2013. London, UK: The Stationery Office, 2012. - 5712p.

11. Indian Pharmacopoeia. Ghaziabad: Indian Pharmacopoeia Commission, 2010. - 2829p

12. Allen L. V. A formulation for preparing Syrup NF / L. V. Allen // Int. J. Pharm. Compd. - 1997. - 2, № 1. P. 111

13. United States Pharmacopeial Convention / The United States Pharmacopeia, 29th rev, and the National Formulary, 24th ed. Rockville, MD: United States Pharmacopeial Convention, 2006. - 1348 p.

14. Державна Фармакопея України : в 3 т. / Державне підприємство "Український науковий фрармакопейний центр якості лікарських засобів”. - 2-ге вид. Харків, 2015. - Т. 1. - 1130 с.

15. Гризодуб А. И. Стандартизованные процедуры валидации методик контроля качества лекарственных средств / А. И. Гризодуб. - Харьков : Государственное предприятие "Украинский научный фрармакопейный центр качества лекарственных средств", 2016. - 396 с.

\section{REFERENCES}

1.Alfred-Ugbenbo, D., Zdoryk, O.A., Georgiyants, V.A., \& Schnatz, R. (2016). Compounding in Nigeria. Int. J. Pharm. Compd., 20 (3), 89-192

2. Valiev, A.K., Zdoryk, O.A., \& Georgiyants, V.A. (2014). Izuchenie khimicheskoy stabilnosti glaznykh kapel tsefazolina natriya aptechnogo prigotovleniya [Chemical stability of pharmacy-compounded Cefazolin sodium eye drops]. Khimiko-farmatsevticheskiy zhurnal - Chemical and Pharmaceutical Journal, 48 (11), 78-80 [in Russian]

3. Alfred-Ugbenbo, D.S., Zdoryk, O.A., \& Georgiyants V.A. (2016). Prescription analysis for extemporaneous preparations in hospital pharmacies of Southern Nigeria. Management, Economy and Quality Assurance in Pharmacy, 3 (47), 46-51.

4. Allen, L.V., Bassani, G.S., Elder, E.J., \& Parr, A.F. (2017). Strength and stability testing for compounded preparations. United States Pharmacopoeia 2015. Retrieved from: http://www.usp.org/sites/default/files/usp_ pdf/EN/ healthcareProfessionals/strength-stabilitytesting- compounded-preparations.pdf

5. Loyd, V.A. (2012). Current \& practical compounding information for the pharmacist. Secundum Artem., 17 (1), 1-4.

6. Navid, F., Christensen, R., Minkin, P., Stewart, C.F., Furman, W.L., \& Baker, S. Stability of sunitinib in oral suspension. Ann. Pharmacother. 42, 962-966.

7. Kennedy, R., Groepper, D., Tagen, M., Christensen, R., Navid, F., \& Gajjar, A. (2010). Stability of cyclo- phosphamide in extemporaneous oral suspensions. Ann. Pharmacother., 44, 295-301.

8. (2011). Japanese pharmacopoeia $16^{\text {th }}$ ed. Ministry of Health, Labour and Welfare. Tokyo.

9. European pharmacopoeia $7^{\text {th }}$ edition. Council of Europe: Strasbourg; 2011.

10. British pharmacopoeia 2013. Vol 5. London, UK: The Stationery Office; 2012.

11. Indian Pharmacopoeia. Ghaziabad: Indian Pharmacopoeia Commission; 2010.

12. Allen, L.V. (1997). A formulation for preparing Syrup NF. IJPC, 2 (1), 111

13. United States Pharmacopeial Convention. The United States Pharmacopeia, 29th rev, and the National Formulary, 24th ed. Rockville, MD: United States Pharmacopeial Convention, 2006.

14. Derzhavna Farmakopeia Ukrainy: $v 3$ tomakh. [State Pharmacopoeia of Ukraine: in 3 vol.]. Kharkiv: Ukrainian Scientific Pharmacopoeial Center for Quality of Medicines; 2015 [in Ukrainian].

15. Gryzodub, A.I. (2016). Standartizovanye protsedury validatsii metodik kontrolya kachstva lekarstvennykh sredstv [Process validation of standardized quality control procedures for medicines]. Kharkov: Gosudarstvenoe predpriyatiya "Ukrainskiy Nauchnyy Farmakopeynyy tsentr kachestva lekarstvennykh sredstv [in Russian]. 


\section{ВАЛІДАЦІЯ МЕТОДИКИ КІЛЬКІСНОГО ВИЗНАЧЕННЯ ФУРОСЕМІДУ В ЕКСТЕМПОРАЛЬНО ВИГОТОВЛЕНОМУ СИРОПІ}

\section{Резюме}

Вступ. Екстемпоральні сиропи можуть бути виготовлені із застосуванням субстанцій або готових лікарських препаратів як активного фрармацевтичного інгредієнта. Існує необхідність у розробці та валідації аналітичних методик, які можна використовувати для контролю якості сиропів аптечного виготовлення, що містять ффуросемід.

Мета дослідження - розробка та валідація методики кількісного визначення фуросеміду в екстемпоральних сиропах, виготовлених як з чистої субстанції, так і готових лікарських засобів.

Методи дослідження. Для запропонованої УФ-спектрофротометричної методики кількісного визначення були визначені умови аналізу, пробопідготовка, валідаційні характеристики. Зразки суспензій субстанції і подрібнених таблеток розчиняли в 0,1 М розчині натрію гідроксиду й оцінювали спектрофотометрично в ультрафріолетовій ділянці світла при довжині хвилі 271 нм з використанням методу питомого показника поглинання.

Результати й обговорення. Зразки відповідали закону Бугера-Ламберта-Бера в діапазоні концен-

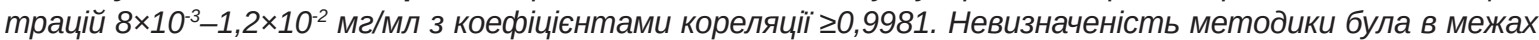
критичного значення похибки (0,72\% $\leq$ тах $\left.{ }_{\text {As}}\right)$ для зразків сиропу, що містили субстанцію, і тих зразків сиропу, які містили комерційні таблетки. Відтворюваність результатів дослідження зразків сиропу фруросеміду із субстанції і подрібнених таблеток становила $(99,92 \pm 0,54)$ та $(99,14 \pm 0,16)$ \% відповідно. Усі проаналізовані зразки екстемпоральних лікарських засобів відповідали критеріям валідаційних характеристик (специфрічність, лінійність, прецизійність, правильність у діапазоні застосування 80-120 \% від номінального вмісту) для допусків вмісту $\pm 10 \%$.

Висновки. За результатами валідації доведено, що цей метод може бути правильно відтворений і придатний для використання у фрармацевтичному аналізі. Даний метод планується застосовувати для оцінки однорідності вмісту і в поєднанні з іншими методами, а також з метою дослідження хімічної стабільності сиропів фруросеміду екстемпорального виготовлення.

КЛЮЧОВІ СЛОВА: фуросемід; екстемпоральні лікарські засоби; УФ-спектрофротометрія; валідація аналітичних методик.

Д. Альфред-Угбенбо, А. А. Здорик, В. А. Георгиянц НАЦИОНАЛЬНЫЙ ФАРМАЦЕВТИЧЕСКИЙ УНИВЕРСИТЕТ, ХАРЬКОВ

\section{ВАЛИДАЦИЯ МЕТОДИКИ КОЛИЧЕСТВЕННОГО ОПРЕДЕЛЕНИЯ ФУРОСЕМИДА В ЭКСТЕМПОРАЛЬНО ИЗГОТОВЛЕННОМ СИРОПЕ}

\section{Резюме}

Вступление. Экстемпоральные сиропы могут быть изготовлены с применением субстанций или готовых лекарственных препаратов в качестве активного фрармацевтического ингредиента. Существует необходимость в разработке и валидации аналитических методик, которые можно использовать для контроля качества сиропов аптечного изготовления, содержащих фуросемид.

Цель исследования - разработка и валидация методики количественного определения фруросемида в экстемпоральных сиропах, изготовленных как из чистой субстанции, так и готовых лекарственных средств.

Методы исследования. Для предложенной УФ-спектрофотометрической методики количественного определения были определены условия анализа, пробоподготовка, валидационные характеристики. Образцы суспензий субстанции и измельченных таблеток растворяли в 0,1 М растворе натрия гидроксида и оценивали спектрофротометрически в ультрасриолетовой области света при длине волны 271 нм с использованием метода удельного показателя поглощения.

Результаты и обсуждение. Образцы соответствовали закону Бугера-Ламберта-Бера в диапазоне концентраций $8 \times 10^{-3}-1,2 \times 10^{-2}$ мг/мл с коэффрициентами корреляции $\geq 0,9981$. Неопределенность мето- 
дики была в пределах критического значения погрешности $\left(0,72 \% \leq m a x \Delta_{A s}\right)$ для образцов сиропа, содержащих субстанцию, и тех образцов сиропа, которые содержали коммерческие таблетки. Воспроизводимость результатов исследования образцов сиропа фуросемида из субстанции и измельченных таблеток составила $(99,92 \pm 0,54)$ и $(99,14 \pm 0,16)$ \% соответственно. Все проанализированные образцы экстемпоральных лекарственных средств соответствовали критериям валидационных характеристик (специфочность, линейность, прецизионность, правильность в диапазоне применения 80-120 \% от номинального содержания) для допусков содержания $\pm 10 \%$.

Выводы. По результатам валидации доказано, что этот метод может быть правильно воспроизведен и пригоден для использования в фрармацевтическом анализе. Данный метод планируется применять для оченки однородности содержания и в сочетании с другими методами, а также с целью исследования химической стабильности сиропов фруросемида экстемпорального приготовления.

КЛЮЧЕВЫЕ СЛОВА: фруросемид; экстемпоральные лекарственные средства; УФ-спектрофотометрия; валидация аналитических методик.

Received 19.04.17

Address for correspondence: D. Alfred-Ugbenbo, National University of Pharmacy, Pushkinska Street, 53, Kharkiv, 61002, Ukraine, e-mail: audeghinmotei@gmail.com. 